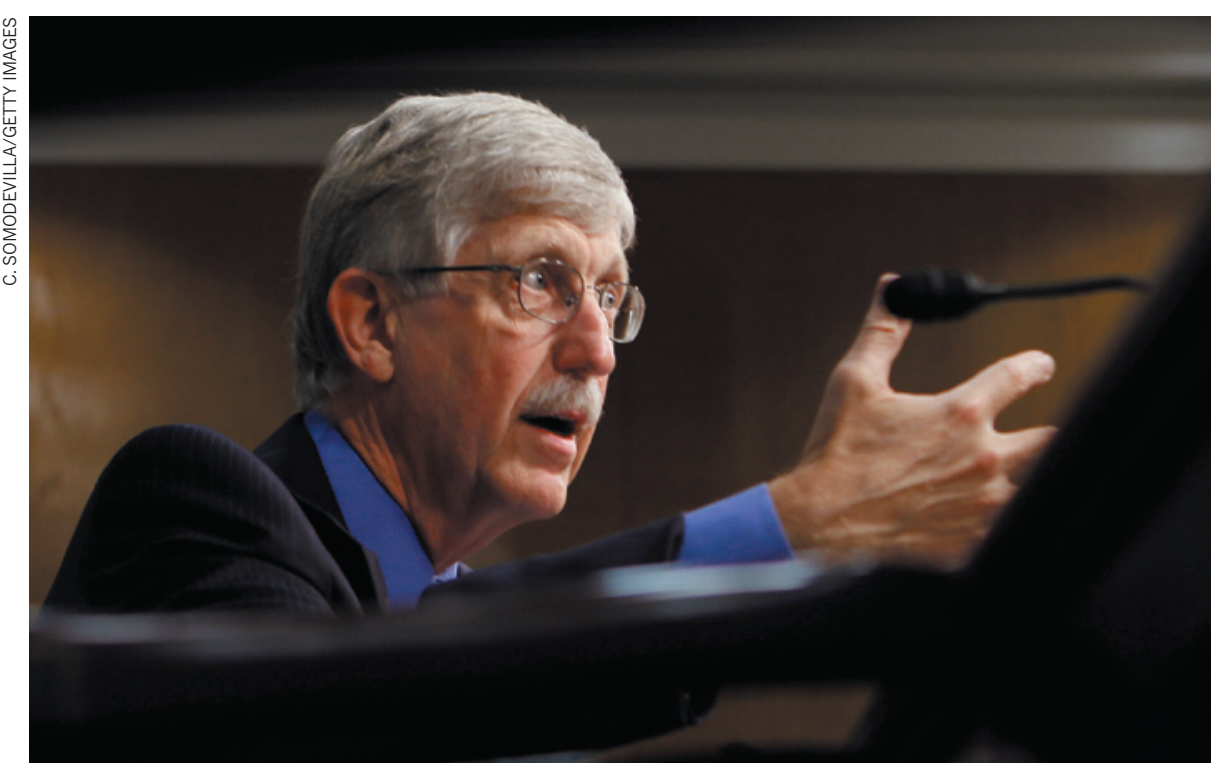

NIH director Francis Collins seems to have secured government backing for a translational-science centre.

\title{
FUNDING
}

\section{Last-minute wins for US science}

\section{Bill tops up health, energy and translational-science spending.}

\section{BY IVAN SEMENIUK AND SUSAN YOUNG}

A year-end push by the US Congress to pass a \$915-billion spending bill has delivered on a key initiative proposed by Francis Collins, director of the National Institutes of Health (NIH).

In addition to funding the NIH at nearly $\$ 30.7$ billion for the 2012 fiscal year, the bill dissolves the National Center for Research Resources (NCRR) and allocates a large portion of its budget - roughly $45 \%$ - to the creation of a National Center for Advancing Translational Sciences (NCATS). It is the biggest organizational change at the biomedical agency in decades.

The translational-science centre was proposed by Collins late last year and fasttracked by the administration of President Barack Obama for establishment in 2012. But the dissolution of the NCRR has met with some resistance within the NIH, particularly from those worried about the fate of its programmes, which will be parcelled out to other NIH institutes and the director's office (see Nature 471, 15-16; 2011). And in June, Denny Rehberg (Republican, Montana), chairman of the House Committee on Appropriations for Labor, Health and Human Services, Education, and Related Agencies objected to not having into the Global Fund to Fight AIDS, Tuberculosis and Malaria. Its \$298-million share will now be covered by the Department of State. Overall, the NIH receives $\$ 299$ million more than last year.

The omnibus bill also includes allocations for the Department of Energy and the Environmental Protection Agency (see 'Science by numbers'). Funding for some agencies, including NASA and the National Science Foundation (NSF), was established in a bill that passed on 17 November (see Nature 479, 455-456; 2011).

The Centers for Disease Control and Prevention (CDC) in Atlanta, Georgia, will also see a small increase from last year's allocation, some of which comes from the mammoth healthcare reform bill that Obama championed in 2010. But Karl Moeller, executive director of the Campaign for Public Health in Washington DC, worries about a longer-term decline in the agency's discretionary budget and about the CDC's lack of champions on Capitol Hill. "If you poll the public, they love prevention, but funding that, for some reason, just doesn't excite members of Congress," says Moeller.

Energy research will see a small rise in 2012. The bill allocates $\$ 4.9$ billion to the Department of Energy's Office of Science - roughly $1 \%$ over its 2011 figure - and $\$ 275$ million to the Advanced Research Projects AgencyEnergy (ARPA-E) to pursue high-risk, highreturn projects. The latter figure is far below the president's ambitious request of $\$ 550$ million for ARPA-E, but it will allow the fledgling agency to proceed with funding a new round of projects (see Nature 471, 145-146; 2011).

Climate science has come under particular scrutiny, a reflection of Republican antipathy towards the regulation of greenhouse-gas emissions. The bill requires the administration to provide a detailed account of money spent on programmes related to climate change in 2011. The Environmental Protection Agency's budget has been cut by $3.4 \%$, with a $\$ 14$-million reduction in funding for clean-air and climate-research programmes. The bill does, however, make $\$ 10$ million available to the state department to contribute to the Intergovernmental Panel on Climate Change and the United Nations Framework Convention on Climate Change.

\section{SCIENCE BY NUMBERS}

Selected figures from the latest spending bill passed by the US Congress, compared with the president's 2012 request and previous fiscal year allocations (US\$ million).

\begin{tabular}{|c|c|c|c|c|}
\hline & 2010 actual & 2011 estimated & 2012 requested & 2012 passed \\
\hline National Institutes of Health & 30,784 & 30,399 & 31,456 & 30,698 \\
\hline Environmental Protection Agency & 10,281 & 8,682 & 8,973 & 8,463 \\
\hline $\begin{array}{l}\text { Centers for Disease Control and } \\
\text { Prevention (discretionary) }\end{array}$ & 6,390 & 5,649 & 5,817 & 5,668 \\
\hline $\begin{array}{l}\text { Department of Energy's Office of } \\
\text { Science }\end{array}$ & 4,964 & 4,858 & 5,416 & 4,889 \\
\hline US Geological Survey & 1,112 & 1,084 & 1,118 & 1,070 \\
\hline
\end{tabular}

Sources: White House OMB, House Committee on Appropriations, CDC 